\title{
Quality of Primary Health Care models for brazilian children
}

\author{
Qualidade dos modelos de Atenção Primária à Saúde para crianças brasileiras \\ Calidad de los modelos de Atención Primaria de Salud para niños brasileños
}

Received: 06/26/2021 | Reviewed: 07/04/2021 | Accept: 07/06/2021 | Published: 07/16/2021

\author{
Beatriz Díaz-Fabregat \\ ORCID: https://orcid.org/0000-0001-9349-7033 \\ Western São Paulo University, Brazil \\ E-mail: bdf930402@gmail.com \\ Wilmer Ramírez-Carmona \\ ORCID: https://orcid.org/0000-0002-5574-1119 \\ Western São Paulo University, Brazil \\ E-mail: wilmerramirezcarmona@gmail.com \\ Eliane Cristina Gava Pizi \\ ORCID: https://orcid.org/0000-0002-8750-7669 \\ Western São Paulo University, Brazil \\ E-mail: elianepizi@unoeste.br \\ Juliane Avansini Marsicano \\ ORCID: https://orcid.org/0000-0002-8213-1754 \\ Western São Paulo University, Brazil \\ E-mail: juavansini@yahoo.com.br \\ Rosana Leal do Prado \\ ORCID: https://orcid.org/0000-0002-5897-2799 \\ Western São Paulo University, Brazil \\ E-mail: rosanahb@yahoo.com.br
}

\begin{abstract}
Aim. To evaluate the quality of Primary Health Care (PHC) models for Brazilian children. Methods. A cross-sectional study was performed with 516 parents or guardian of children in the public preschools from a city in São Paulo State, Brazil. The participants completed the questionnaires on the perception of the quality of the PHC (Primary Care Assessment Tool-PCATool), and the socioeconomic conditions in their families. The data were analyzed by statistical tests (95\% confidence level). Results. Private services, Family Health Strategies (FHS), and Conventional Health Care (CHC) were the modalities of PHC used by children. Among the three modalities, in all groups were observed statistically significant differences $(\mathrm{p}<0.001)$, the best quality of care was provided by FHS $(8.22 \pm 1.69)$. The CHC $(5.69 \pm 1.34)$ and the private service $(6.65 \pm 0.99)$ need improvement in accessibility, continuity of care, integrality, family, and community orientation. The socioeconomic class of the families was associated with modalities of PHC $(p<0.001)$. Conclusions. The quality of primary care for children in the public health system still requires much improvement, primarily in conventional model. However, the Family Health Strategies was the model that presented the best quality of primary health care for children.
\end{abstract}

Keywords: Child, preschool; Primary health care; Quality of health Care; Socioeconomic factors.

\section{Resumo}

Objetivo. Avaliar a qualidade dos modelos de Atenção Primária à Saúde (APS) para crianças brasileiras. Metodologia. Um estudo transversal foi realizado com 516 pais ou responsáveis por crianças da creche pública de um município do interior do estado de São Paulo. Os participantes responderam aos questionários sobre a percepção da qualidade da APS (Primary Care Assessment Tool-PCATool) e sobre as condições socioeconômicas da família. Os dados foram analisados por meio de testes estatísticos (nível de confiança de 95\%). Resultados. Os serviços privados, as Estratégias de Saúde da Família (ESF) e a Atenção Convencional à Saúde (ACS) foram as modalidades de APS utilizadas pelas crianças. Dentre as três modalidades, em todos os grupos foram observadas diferenças estatisticamente significativas ( $\mathrm{p}<0,001$ ), a melhor qualidade do atendimento foi prestada pela ESF $(8,22 \pm 1,69)$. A ACS $(5,69 \pm 1,34)$ e o serviço privado $(6,65 \pm 0,99)$ necessitam de melhorias na acessibilidade, continuidade do cuidado, integralidade, orientação familiar e comunitária. A classe socioeconômica das famílias teve associação com as modalidades de APS ( $\mathrm{p}<0,001)$. Conclusão. A qualidade da atenção primária infantil da rede pública de saúde ainda requer muitas melhorias, principalmente no modelo convencional. Por outro lado, a atenção primária às crianças de melhor qualidade foi apresentada pelo modelo baseado na atenção à família.

Palavras-chave: Pré-escolar; Atenção primária à saúde; Qualidade da assistência à saúde; Fatores socioeconômicos. 


\section{Resumen}

Objetivo. Evaluar la calidad de los modelos de Atención Primaria de Salud (APS) para niños brasileños. Metodología. Se realizó un estudio transversal con 516 padres o tutores de niños de una guardería pública en una ciudad del interior del estado de São Paulo. Los participantes respondieron cuestionarios sobre la percepción de la calidad de la APS (Primary Care Assessment Tool-PCATool) y sobre las condiciones socioeconómicas de la familia. Los datos se analizaron mediante pruebas estadísticas (nivel de confianza del 95\%). Resultados. Los servicios privados, las Estrategias de Salud de la Familia (ESF) y la Atención de Salud Convencional (ASC) son las modalidades de APS utilizadas por los niños. Entre las tres modalidades, en todos los grupos se observaron diferencias estadísticamente significativas ( $\mathrm{p}<0,001)$, la mejor calidad de atención la brindó la ESF $(8,22 \pm 1,69)$. La ASC $(5,69 \pm 1,34)$ y el servicio privado $(6,65 \pm 0,99)$ necesitan de mejoras en la accesibilidad, la continuidad asistencial, la integralidad, la orientación familiar y comunitaria. La condición socioeconómica de las familias se asoció con las modalidades de APS ( $p<0,001)$. Conclusión. La calidad de la atención primaria infantil en la red pública de salud todavía requiere muchas mejoras, especialmente en el modelo convencional. Por otro lado, el modelo de atención primaria infantil de mejor calidad fue el basado en la atención a la familia.
\end{abstract}

Palabras clave: Preescolar; Atención primaria de salud; Calidad de la atención de salud; Factores socioeconómicos.

\title{
1. Introduction
}

Health is a fundamental human right and an extremely important aspect of society that requires interventions in social, governmental, economic, and health areas. Hence, governments have the obligation to care for the health of their people and should consider the implementation of primary health care (PHC) as a strategy to guarantee this right (OPS, 1978).

In health systems organized as networks, PHC is considered the main entrance into the system; PHC consists of an inseparable set of structural elements from the system (Starfield, 1992). The Brazilian health system is made up of a private sector (in its various forms) and a single publicly managed health system (Pilotto \& Celeste, 2019). From its beginning, the publicly managed health system has undergone improvements, and the most important of these improvements has been the development of the Family Health Strategies (FHS) model, employed in addition to the traditional model of Conventional Health Care (CHC) (Almeida, 2018).

The FHS and CHC models are the two modalities of PHC available through the Brazilian public health system. In the CHC model, as part of a model of primary care should be able to offer health promotion, prevention, treatment and rehabilitation to patients, the professionals provide traditional care based on spontaneous demand for care and with poor interaction with the community (Martins et al. 2016). However, in the FHS model, community-based, family-focused care is provided and care planning is offered to a delimited population (Martins et al. 2016).

Primary health care services, including solving the most common health problems and detecting diseases in the early stages, are offered to the population, with the benefit of PHC being an affordable and efficient health system (Baggaley et al. 2017). As the Brazilian public health system is supported by taxpayers (Becerril-Montekio, Medina \& Aquino, 2011), the costbenefit, quality, and effectiveness of PHC services are very important to the community, which represent its primary users.

A health system that offers higher quality PHC would reduce costs and more effectively provide social welfare to families (Ferrer \& Grisi, 2016). During an economic and political crisis, family health care tends to be more critical due to reductions in socioeconomic resources; austerity measures such as tax increases and budget reductions; and other factors that can affect quality of health (Costa, 2016).

These effects are most severe in large systems such as that of Brazil. In Brazil, a tremendous amount of people are affected, and the country has a high level of social inequality. In this situation, the quality of the PHC provided to children is very important because it contributes to the delivery of effective health services and quality of life in this vulnerable population (Baldani et al. 2017). Children's health care can be affected by economic crises, social inequality, and austerity measures because these factors affect access to health care, increase the costs of medical plans, overload the public health system, and reduce hospital budgets and assistance to programs (Sissouras, 2014). 
Thus, the criteria to assess the quality of a health system should include aspects, properties, constituents, or dimensions of the health care process and should be evaluated regularly, and the perception of the users are very important for the evaluation of quality of PHC (Harzheim et al. 2010). The aim of this study was to evaluate the quality of PHC models for Brazilian children.

\section{Methodology}

According to Levin (2006), the study is classified as a cross-sectional research. The methodology was performed in accordance with Strengthening The Reporting of Observational Studies in Epidemiology (STROBE) guidelines (Vandenbroucke et al. 2014), among users of PHC services in a city in São Paulo State, Brazil. The city has over 220,000 inhabitants, and its available health services include both public and private PHC. Public PHC includes both FHS and CHC. In order to evaluate the quality of PHC for children, participants of the study were recruited from the public schools of the city.

The participants in the study were parents or guardians of preschool children that used any form of PHC. The FHS coverage in Brazil (64.0\%) was used in the sample calculation (Neves et al. 2018). With a 95\% confidence level, 5\% sampling error, and 1.4 design effect (Luiz \& Magnanini, 2000) the estimated sample size needed was 496 children. Children of the participants from 13 public preschools were randomly evaluated. Stratified sampling was performed based on the size of schools (small [8 schools], medium [3 schools] and large [2 schools]). Schools were then randomly selected using a statistical software program (R 3.6.1, R Foundation for Statistical Computing, Vienna, Austria). In the selection of the participants was performed with simple random sampling and was included in the study parents or guardians of children that completed all information of the questionnaires. All participants provided prior written informed consent. The study was approved by the Ethics Committee on Human Research (01788818.8.0000.5515) and was conducted in accordance with the Declaration of Helsinki.

Public services (FHS and CHC) and private services of the PHC were evaluated. Although the instrument is commonly used to evaluate the public system, including the assessment of private systems primary attention it was a differential in this research, because it represents an interesting contrast in the results. The data were collected using the PCATool-Brazil (Harzheim et al. 2010) for children service users, which had been administered to the parent or guardian. The questionnaire was completed by the participants with the help of the researcher. It was used to analyze the primary outcomes (essential attributes) and secondary outcomes (general attributes) in PHC.

The essential attributes evaluated were as follows: degree of health services affiliation ( 3 items), first contact access use (3 items), first contact access - accessibility (6 items), continuity of care (14 items), coordination - care integration (5 items), coordination - information system (3 items), integrality - available services ( 9 items), integrality - services provided (5 items). general attributes evaluated were as follows: essential attributes and derivate attributes such as family orientation (3 items) and community orientation (4 items). The answers had a maximum value of 10 points and in the assessment of the quality of health services, the cut-off point for the evaluation was 6.6 (Harzheim, Pinto, Hauser \& Soranz, 2016), representing the minimum quality of service value in the instrument.

Socioeconomic class was determined with a socioeconomic instrument (Graciano \& Lehfeld, 2010), which was administered to the child's parent or guardian. Socioeconomic condition was evaluated by variables such as the following: family size, family income (minimum wage = USD 233/month), education level, occupation, housing situation and condition, and social benefits (e.g., benefits from the Brazilian Income Transfer Program [Bolsa Família, in Portuguese]). The instrument is able to classify families according to the following socioeconomic classes: lower lower class, upper lower class, lower middle class, middle class, upper middle class and upper class (Graciano \& Lehfeld, 2010). 
The Chi-square test was used to examine the associations between socioeconomic class and modalities of service, and between socioeconomic class and social benefits. The Kruskal-Wallis tests was used to compare the quality of PHC among services ( $95 \%$ confidence level).

\section{Results}

The Table 1 shows socioeconomic factors as family size, family income, educational level, and social benefits among the Primary Health Care. Private services (94 children), FHS (154 children), and CHC (268 children) were the PHC modalities used the most by the children.

\begin{tabular}{|c|c|c|c|c|c|c|}
\hline \multirow[b]{2}{*}{ Family size } & \multicolumn{2}{|c|}{ Private Health Services $(\mathrm{n}=94)$} & \multicolumn{2}{|c|}{ Family Health Strategy $(\mathrm{n}=154)$} & \multicolumn{2}{|c|}{ Conventional Health Care $(n=268$} \\
\hline & $\mathbf{N}$ & $\%$ & $\mathbf{N}$ & $\%$ & $\mathbf{N}$ & $\%$ \\
\hline 1-2 people per household $(n=35)$ & 8 & 22.86 & 8 & 22.86 & 19 & 54.28 \\
\hline 3-4 people per household $(n=346)$ & 75 & 31.68 & 92 & 26.59 & 179 & 41.73 \\
\hline 5-6 people per household $(n=117)$ & 9 & 7.69 & 49 & 41.88 & 59 & 50.43 \\
\hline More than 7 people per household $(n=18)$ & 2 & 11.11 & 5 & 27.78 & 11 & 61.11 \\
\hline \multicolumn{7}{|l|}{ Family income } \\
\hline 1/2 MW and 2 MW (USD 117-466) $(n=248)$ & 29 & 11.69 & 87 & 35.08 & 132 & 53.23 \\
\hline $2 \mathrm{MW}$ and $4 \mathrm{MW}$ (USD 467-932) $(\mathrm{n}=203)$ & 55 & 27.09 & 39 & 19.21 & 109 & 53.70 \\
\hline More than 4 MW (USD 933) $(n=28)$ & 10 & 35.71 & 5 & 17.86 & 13 & 46.43 \\
\hline \multicolumn{7}{|l|}{ Educational Level } \\
\hline More than 12 years of education $(n=128)$ & 41 & 32.03 & 27 & 21.09 & 60 & 46.88 \\
\hline 12 years of education $(n=186)$ & 40 & 21.50 & 48 & 25.80 & 98 & 52.70 \\
\hline 9 years of education $(n=106)$ & 10 & 9.43 & 42 & 39.62 & 54 & 50.95 \\
\hline Less than 9 years of education $(n=94)$ & 3 & 3.19 & 35 & 37.23 & 56 & 59.58 \\
\hline Yes $(n=124)$ & 3 & 2.42 & 60 & 48.39 & 61 & 49.19 \\
\hline No $(n=392)$ & 91 & 23.21 & 94 & 23.97 & 207 & 52.82 \\
\hline
\end{tabular}

Source: Authors (2021).

The families' descriptions showed that family with income half of the minimum wage did not use private health services. Families that received social benefits and had lower levels of education were predominantly public services users. Among users of private services, $85 \%$ worked in the production of goods and services or public administration sectors. Accessibility in private services was higher compared with others modalities. Accessibility was lower in CHC. One-quarter of CHC users reported experiencing difficulties when they took their child to a health facility for medical attention, and half of users reported having to wait more than 30 minutes for their child to receive medical care.

The evaluation of the attributes of the Primary Health Care was presented in the Table 2 as mean and standard deviation (SD). In this table the superscript means statistical significance $(\mathrm{p}<0.001)$ ( ${ }^{\mathrm{abc}}$ for all Primary Health Care, ${ }^{\text {ab }}$ Private Health Services and Family Health Strategy, ${ }^{\text {ac }}$ Private Health Services and Conventional Health Care, bc Family Health Strategy and Conventional Health Care). 
Table 2: The attributes of the Primary Health Care.

\begin{tabular}{|c|c|c|c|c|c|c|}
\hline & \multicolumn{2}{|c|}{ Private Health Services $(n=94)$} & \multicolumn{2}{|c|}{ Family Health Strategy $(\mathrm{n}=154)$} & \multicolumn{2}{|c|}{$\begin{array}{l}\text { Conventional Health Care } \\
\qquad(\mathrm{n}=268)\end{array}$} \\
\hline & Mean & SD & Mean & SD & Mean & SD \\
\hline Degree of Health Services Affiliation ${ }^{\text {ac, bc }}$ & 9.28 & 1.90 & 9.48 & 1.64 & 7.69 & 3.04 \\
\hline First Contact Access- Use ac, bc & 9.33 & 1.45 & 9.30 & 1.90 & 8.63 & 2.52 \\
\hline First Contact Access - Accessibility ${ }^{\text {ac, bc }}$ & 8.44 & 1.65 & 7.37 & 2.82 & 5.96 & 2.73 \\
\hline Continuity of Care ${ }^{a c, b c}$ & 7.25 & 1.44 & 7.59 & 2.18 & 5.16 & 2.33 \\
\hline Coordination - Care Integration ac, be & 9.48 & 1.67 & 9.10 & 2.52 & 7.12 & 3.81 \\
\hline Coordination - Information System ac, bc & 8.40 & 1.93 & 8.48 & 1.72 & 6.98 & 1.94 \\
\hline Integrality - Available Services ${ }^{\text {abc }}$ & 3.27 & 3.15 & 8.76 & 2.36 & 5.09 & 2.90 \\
\hline Integrality-Services Provided ${ }^{\text {ab, bc }}$ & 6.13 & 4.35 & 8.67 & 2.82 & 5.60 & 3.77 \\
\hline Family Orientation ${ }^{\text {abc }}$ & 5.34 & 2.71 & 8.14 & 2.71 & 4.21 & 3.11 \\
\hline Community Orientation $^{\text {ab, bc }}$ & 0.57 & 1.71 & 6.26 & 3.81 & 1.19 & 2.32 \\
\hline Essential Scores ${ }^{\text {abc }}$ & 7.63 & 1.09 & 8.52 & 1.53 & 6.49 & 1.37 \\
\hline General Scores abc & 6.65 & 0.99 & 8.22 & 1.69 & 5.69 & 1.34 \\
\hline
\end{tabular}

Source: Authors (2021).)

In the assessment of quality of PHC for children, all groups were observed statistically significant differences $(\mathrm{p}<0.001)$ FHS was found to have higher scores on essential $(8.52 \pm 1.53)$ and general attributes $(8.22 \pm 1.69)$ in comparison to CHC (essential $6.49 \pm 1.37$ and general 5.69 $\pm 1.34 ; \mathrm{p}<0.001$ ) and private services (essential $7.63 \pm 1.09$ and general attributes $6.65 \pm 0.99 ; \mathrm{p}<0.001$ ). For affiliation and first contact use (essential attributes of health services), FHS and private services were found to be superior to $\mathrm{CHC}(\mathrm{p}<0.001)$. These results are represented in Figure 1, and the cut-off point was 6.6 representing the minimum quality of service value in the instrument.

Figure 1: Attributes of Primary Health Care in a public and private services.

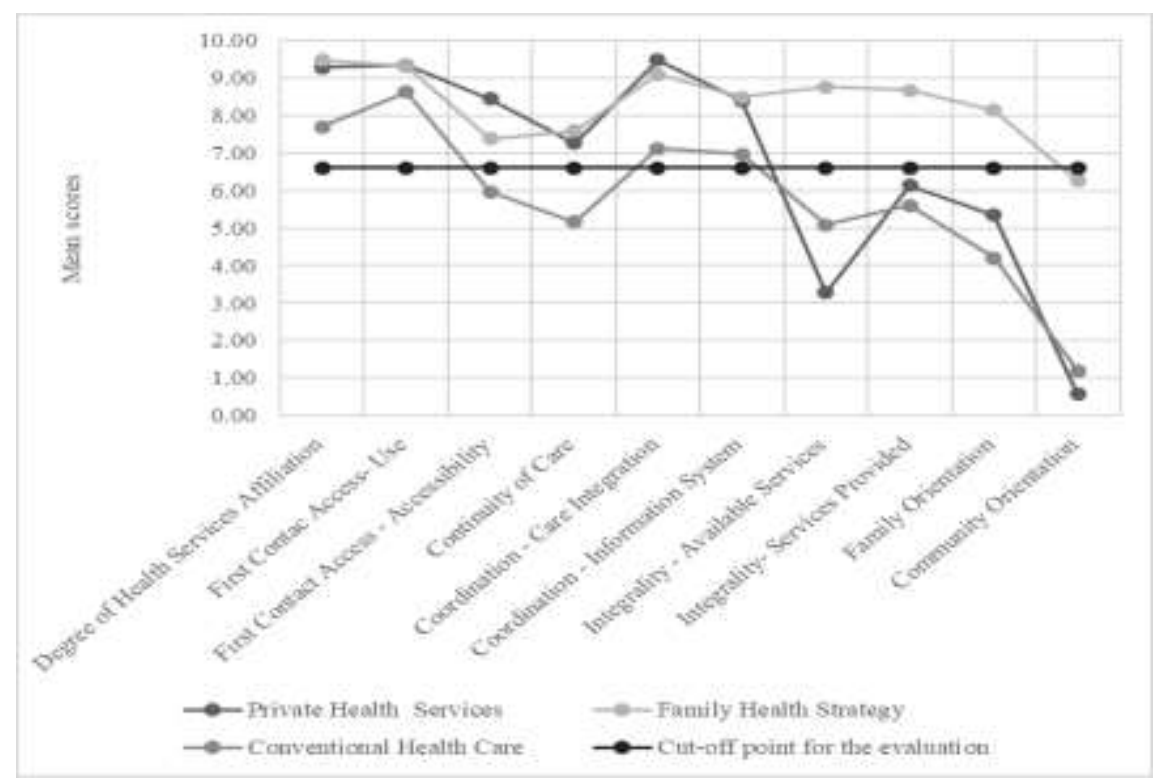

Source: Authors (2021).

The CHC had lower scores for continuity of care and coordination compared with FHS and private services $(\mathrm{p}<0.001)$. Half of the $\mathrm{CHC}$ users were attended by different medical practitioners, and a strong affective link with the child could not be created. FHS was highest in integrality of services and family orientation $(\mathrm{p}<0.001)$. The CHC and the private services were found to have lower scores on derivate attributes (family and community orientation), compared with FHS. Among the users of all three modalities of services, many of the participants had no knowledge of the Local Health Council $(69.71 \%)$. 
During the analysis of the data, the responses of one participant were excluded from the data on general attributes $(n=515)$ because the participant had responded "I do not know" for all items on general attributes; however, this participant's responses were included in the analysis of the association between type of service and socioeconomic class ( $\mathrm{n}=516)$. Figure 2 shows the association between socioeconomic class and Primary Health Care models $(\mathrm{p}<0.001)$.

Figure 2: Socioeconomic class and Primary Health Care models.

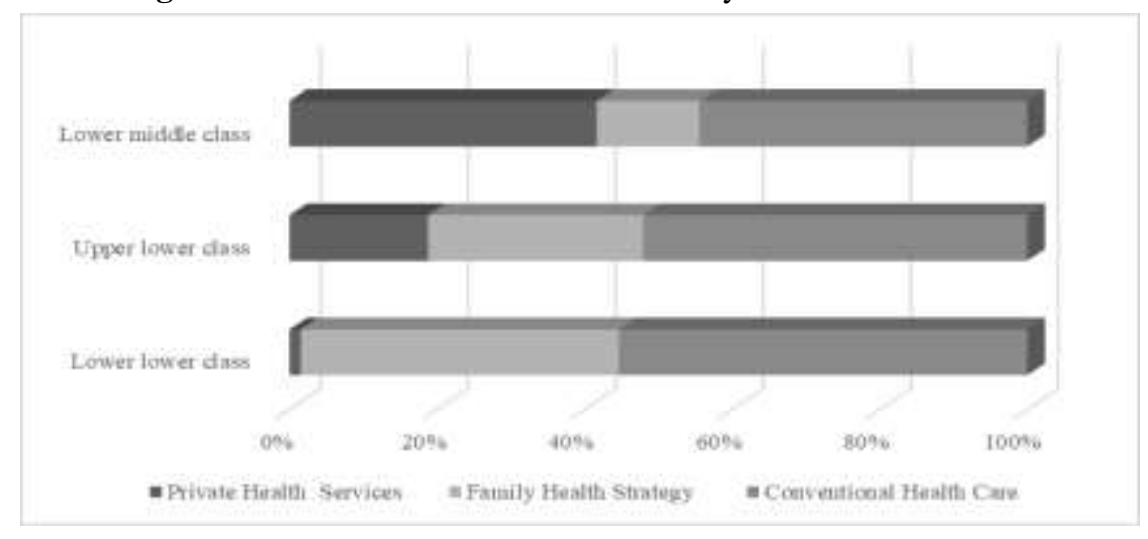

Source: Authors (2021).

It was observed that most families were in the lower socioeconomic classes (any family was superior to lower middle classes). Children with the lowest socioeconomic status were report by their parents as depending almost exclusively on the public health system (including both FHS and CHC), and $81 \%$ of the families were exclusive users of the public health system. In contrast, families in the higher socioeconomic classes made more use of private services, and this association was statistically significant $(\mathrm{p}<0.001)$. Furthermore, there were more users of FHS services in the lower lower class compared with the other classes. Social benefits were associated with socioeconomic class $(p<0.001)$; the lower the socioeconomic class of a family, the more likely the family was to be receiving more social benefits.

\section{Discussion}

The quality of FHS services provided to children was found to be superior to that of the traditional model (CHC). This finding may be due to the fact that FHS shares similar characteristics with the ideal model of PHC. A higher score in the attributes represents better quality of primary care, and better quality of life in children (Baldani et al. 2017).

Brazil is a country with a high level of inequality among its population. Improvements in the quality of primary care for children can mitigate this situation in the health care system. The services provided through FHS can correct inequalities that impact the health of children even when they are affected by poor living and health conditions (Oliveira, Moreira \& Luiz, 2019). This modality of primary care can aid in the reduction of socioeconomic inequalities for children and change the nature of health investment programs (Shimizu \& Ramos, 2019). Children with less use of PHC services (both FHS and CHC) were more at risk for serious diseases with a high level of cost to the system. This situation can cause an overload in care and hospitalization in the primary care system (Schilling Mendonça, Bielefeldt Leotti, Soares Dias-da-Costa \& Harzheim, 2017).

In FHS, the focus is on the community and families, a relationship that supports the increase of service affiliation levels (Castro et al. 2019). Mothers that receive prenatal care at FHS increase the affiliation their children to health services (Feldens et al. 2018). However, the CHC is a traditional model (Castro et al. 2019), and patients must seek medical attention in order to receive it (Martins et al. 2016), resulting in a lower degree of adherence to this type of primary care. 
Additionally, the family's affiliation with the health service is associated with the continuity of care for their children (Feldens et al. 2018), and an assessment of the quality of care with higher criteria. Lower scores on continuity of care for the CHC model may suggest that in the traditional model, in which patients must initially seek care, the treatment of the consequences of diseases is prioritized over the causes of diseases, which leads to less prevention of disease.

A strong relationship between the health professional and the patient increases mutual trust and facilitates continuity of care (Diniz et al. 2016). In services where different physicians are responsible for the delivery of care, the quality of care can be compromised. In FHS, the health professionals' work with the family leads to greater continuity of care (Nascimento et al. 2019).

There were no significant findings for coordination of attention; however, the referral and counter-referral system remain precarious in the public system (Hermida et al. 2019), mainly in the CHC. A possible limitation of this study is related to the fact that participants enrolled in private services may not know exactly the differences between primary and secondary care. Difficulties in the coordination of care for children can affect the quality of PHC services, causing a lack of connection within and between health care levels (Hermida et al. 2019).

The integrality scores were generally low, similar to the scores of other studies (Diniz et al. 2016; Araujo et al. 2018), indicating the need for more health promotion and disease prevention in the health care of children. Hygiene awareness, methods of dealing with behavioral problems during the development of the child, vaccination for disease prevention, and knowledge of family planning are necessary elements that increase the quality of PHC (Harzheim et al. 2010). Initiatives such as vaccine programs can have positive effects, reducing mortality and, consequently, have a positive impact on the costbenefits of the investment in health (Shimizu \& Ramos, 2019).

Scores on family and community orientation were low for all services, similar to other studies on PHC (Araujo et al. 2018; Sim et al. 2019). Political participation in the decision-making on matters that affect the community and the evaluation of risk factors for the development of diseases enable the development of preventive strategies and the prioritization of health policies that improve the welfare of families and increase the empowerment of the community (George, Mehra, Scott \& Sriram, 2015). It was found that many parents had never heard of the Local Health Council, which is concerning because the council is the primary method of community participation in the management and evaluation of the public system (BecerrilMontekio, Medina \& Aquino, 2011). This situation may be a consequence of the low social stimulus to participate in decisions that affect the community, general lack of knowledge, or the absence or low dissemination of information about the Local Health Council.

The families' access to other services such as health plans is limited by socioeconomic condition. Increase of socioeconomic status, also increases the preference for private services (Pilotto \& Celeste, 2019). On the other hand, when people use private services, they are paying more for health care, which can affect the family economically. The rise in private management is one driver of higher expenditures in the system (McGregor et al. 2017).

This study found that many families that used private services had members who worked in public administration sectors, which may have made private health services more accessible to these families, even to those with lower than middleclass status. People with a private health plan tend to use medical services more than people without such a plan (Pilotto \& Celeste, 2019). Considering that this use of private services had low integrality, it is possible that the children are subjected to overexposure to treatment without the health promotion and the prevention of diseases that could meet their actual health needs.

However, there were more users of FHS services in the lower lower class than in the lower middle class, in order to promote equity (a principle of the public system) by giving more to those who need more. Even though FHSs have defined populations, they are prioritized in places with lower socioeconomic conditions (Costa, 2016). As a result, FHSs do not cover 
$100 \%$ of the children in the population, only the most disadvantaged families, Brazil is in a period of economic recession where the increase in FHS services are very limited for to reach this coverage.

Social benefits such as those of the Brazilian Income Transfer Program increase the probability of improving utilization of PHC services for children; increasing the prevention of pediatric diseases; and immunization, orientation, and monitoring of the development of children (Shei, Costa, Reis \& Ko, 2014), thus improving the quality of primary care for children. This social program may improve the socioeconomic condition of families because it considers the importance of the continuity of education and health care in the care of children.

There might have been a limitation in the study regarding subjectivity of the participants' responses and the veracity of their information, but despite this limitation, the evaluation of the users of the quality of primary care as the main beneficiaries of the service is considered very important to strengthen the primary health care. PHC models based on family and community care had more quality and adherence to health system than other models. Therefore, also had more impact for families.

\section{Conclusion}

Family Health Strategies was the model that presented the best quality of primary health care for children. Private service was the second-best model in terms of quality, with deficits in the essential (integrality) and derived (family and community orientation) attributes. Conventional Health Care, which was based on demand, had the poorest quality of primary health care for children. There is still much need for improvement in the quality of primary care for children in the public health system, primarily in CHC. Furthermore, future research are necessary to measure the impact of the quality of primary services on the health of the child population.

\section{Acknowledgments}

The authors gratefully acknowledge the support of study with a scholarship provided by Coordination for the improvement of higher education, National Council of Technological and Scientific Development (CAPES).

\section{References}

Almeida, P. F. (2018). Primary health care in Brazil and the 40 years of Alma-Ata: acknowledging the challenges in order to move forward. Cadernos de saúde pública, 34: e00136118. 10.1590/0102-311X00136118

Araujo, J. P., Viera, C. S., Oliveira, B. R. G., et al. (2018). Assessment of the essential attributes of Primary Health Care for children. Revista brasileira de enfermagem, 71: 1366-1372. 10.1590/0034-7167-2017-0569

Baggaley, R. F., Irvine, M. A., Leber, W., Cambiano, V., Figueroa, J., McMullen, H., Anderson, J., Santos, A. C., Terris-Prestholt, F., Miners, A., Hollingsworth, T. D., \& Griffiths, C. J. (2017). Cost-effectiveness of screening for HIV in primary care: a health economics modelling analysis. The lancet. HIV , 4(10), e465-e474. 10.1016/S2352-3018(17)30123-6

Baldani, M. H., Rocha, J. S., Fadel, C. B., Nascimento, A. C., Antunes, J., \& Moysés, S. J. (2017). Assessing the role of appropriate primary health care on the use of dental services by Brazilian low-income preschool children. Cadernos de saúde pública, 33(11), e00158116. 10.1590/0102-311X00158116

Becerril-Montekio, V., Medina, G., \& Aquino, R. (2011). Sistema de salud de Brasil [The health system of Brazil]. Salud pública de México, 53: S120-S131. Retrieved from https://pubmed.ncbi.nlm.nih.gov/21877078/

Castro, M. C., Massuda, A., Almeida, G., Menezes-Filho, N. A., Andrade, M. V., de Souza Noronha, K., Rocha, R., Macinko, J., Hone, T., Tasca, R., Giovanella, L., Malik, A. M., Werneck, H., Fachini, L. A., \& Atun, R. (2019). Brazil's unified health system: the first 30 years and prospects for the future. Lancet, 394(10195), 345-356. 10.1016/S0140-6736(19)31243-7

Costa, N.R. (2016). The Family Health Strategy: primary health care and the challenge of Brazilian metropolises. Ciência \& saúde coletiva, 21:1389-98. $10.1590 / 1413-81232015215.24842015$

Diniz, S. G., Damasceno, S. S., Coutinho, S. E., Toso, B. R., \& Collet, N. (2016). Evaluating comprehensiveness in children's healthcare. Avaliação do atributo integralidade na atenção à saúde da criança. Revista gaúcha de enfermagem, 37(4), e57067. 10.1590/1983-1447.2016.04.57067 
Feldens, C. A., Fortuna, M. J., Kramer, P. F., Ardenghi, T. M., Vítolo, M. R., \& Chaffee, B. W. (2018). Family Health Strategy associated with increased dental visitation among preschool children in Brazil. International journal of paediatric dentistry, 28(6), 624-632. 10.1111/ipd.12421

Ferrer, A. P., \& Grisi, S. J. (2016). Assessment of access to primary health care among children and adolescents hospitalized due to avoidable conditions. Revista da Associação Médica Brasileira, 62: 513-523. 10.1590/1806-9282.62.06.513

George, A. S., Mehra, V., Scott, K., \& Sriram, V. (2015). Community Participation in Health Systems Research: A Systematic Review Assessing the State of Research, the Nature of Interventions Involved and the Features of Engagement with Communities. PloS one, 10(10), e0141091. 10.1371/journal.pone.0141091

Graciano, M., \& Lehfeld, N. (2010). Estudo socioeconômico: indicadores e metodologia numa abordagem contemporânea. Serviço Social e Saúde, 9: 157-86. Retrieved from https://doi.org/10.20396/sss.v9i1.8634873

Harzheim, E., Gonçalves, M. R., Oliveira, M. M. C., et al. (2010). Manual do Instrumento de Avaliação da Atenção Primária à Saúde Primary Care Assessment Tool PCATool-Brasil.

Harzheim, E., Pinto, L. F., Hauser, L., \& Soranz, D. (2016). Assessment of child and adult users of the degree of orientation of Primary Healthcare in the city of Rio de Janeiro, Brazil. Avaliação dos usuários crianças e adultos quanto ao grau de orientação para Atenção Primária à Saúde na cidade do Rio de Janeiro, Brasil. Ciência \& saúde coletiva, 21(5), 1399-1408. 10.1590/1413-81232015215.26672015

Hermida, P., Nascimento, E., Echevarría-Guanilo, M. E., Andrade, S. R., \& Ortiga, Â. (2019). Counter-referral in Emergency Care Units: discourse of the collective speech. Revista brasileira de enfermagem, 72(suppl 1), 143-150. 10.1590/0034-7167-2018-0023

Levin, K. A. (2006). Study design III: Cross-sectional studies. Evidence-based dentistry, 7(1), 24-25. 10.1038/sj.ebd.6400375

Luiz, R. R., \& Magnanini, M. M. F. (2000). A lógica da determinação do tamanho da amostra em investigações epdemiológicas. Cadernos saúde coletiva, 8: 9-28. Retrieved from https://www.scienceopen.com/document?vid=ed7003ea-9ad2-45ad-be94-f80e1ee02e41

Martins, J. S., Abreu, S. C. C., Quevedo, M. P., et al. (2016). Comparative Study between Health Care Units with and without Family Health Strategy using PCATool. Revista Brasileira de Medicina de Família e Comunidade, 11: 1-13. Retrieved from https://doi.org/10.5712/rbmfc11(38)1252

McGregor, A. J., Siqueira, C. E., Zaslavsky, A. M., et al. (2017). Do elections matter for private-sector healthcare management in Brazil? An analysis of municipal health policy. BMC health services research, 17: 483. 10.1186/s12913-017-2427-5

Nascimento, A. C., Moysés, S. T., Werneck, R. I., Gabardo, M., \& Moysés, S. J. (2019). Assessment of public oral healthcare services in Curitiba, Brazil: a cross-sectional study using the Primary Care Assessment Tool (PCATool). BMJ open, 9(1), e023283. 10.1136/bmjopen-2018-023283

Neves, R. G., Flores, T. R., Duro, S., Nunes, B. P., \& Tomasi, E. (2018). Time trend of Family Health Strategy coverage in Brazil, its Regions and Federative Units, 2006-2016. Tendência temporal da cobertura da Estratégia Saúde da Família no Brasil, regiões e Unidades da Federação, 2006-2016. Epidemiologia e serviços de saúde, 27: e2017170. 10.5123/S1679-49742018000300008

Oliveira, B. L. C. A., Moreira, J. P. L., \& Luiz, R. R. (2019). The influence of the Family Healthcare Strategy in the use of healthcare services by children in Brazil: an analysis using the Propensity Score Matching (PSM) method of National Health Survey data. Ciência \& saúde coletiva, 24:1495-1505. $10.1590 / 1413-81232018244.05522017$

OPS. (1978). Declaração de Alma-Ata. Conferência Internacional sobre cuidados primários de saúde. Alma-Ata, URSS, 8-10.

Pilotto, L. M., \& Celeste, R. K. (2019). The relationship between private health plans and use of medical and dental health services in the Brazilian health system. Ciência \& saúde coletiva, 24: 2727-2736. 10.1590/1413-81232018247.24112017

Schilling Mendonça, C., Bielefeldt Leotti, V., Soares Dias-da-Costa, J., \& Harzheim, E. (2017). Hospitalizations for primary care sensitive conditions: association with socioeconomic status and quality of family health teams in Belo Horizonte, Brazil. Health policy and planning, 32(10), 1368-1374. 10.1093/heapol/czx103

Shei, A., Costa, F., Reis, M. G., \& Ko, A. I. (2014). The impact of Brazil's Bolsa Família conditional cash transfer program on children's health care utilization and health outcomes. BMC international health and human rights, 14, 10. 10.1186/1472-698X-14-10

Shimizu, H.E., \& Ramos, M.C. (2019). Evaluation of quality of the family health strategy in the Federal District. Revista brasileira de enfermagem, 72: 367374. 10.1590/0034-7167-2018-0130

Sim, S. Y., Jit, M., Constenla, D., Peters, D. H., \& Hutubessy, R. (2019). A Scoping Review of Investment Cases for Vaccines and Immunization Programs. Value in health, 22(8), 942-952. 10.1016/j.jval.2019.04.002

Sissouras, A. (2014). Greek crisis fallout is an opportunity for health. Bulletin of the World Health Organization, 92:8-9. 10.2471/BLT.14.030114

Starfield, B. (1992). Primary care: Concept, evaluation, and policy. Oxford University Press.

Vandenbroucke, J. P., von Elm, E., Altman, D. G., Gøtzsche, P. C., Mulrow, C. D., Pocock, S. J., Poole, C., Schlesselman, J. J., Egger, M., \& Strobe Initiative. (2014). Strengthening the Reporting of Observational Studies in Epidemiology (STROBE): explanation and elaboration. International journal of surgery, 12(12), 1500-1524. 10.7326/0003-4819-147-8-200710160-00010-w1 